\title{
Effectiveness of the use of synthetic analytical structural methods against the ability to begin writing skills in elementary school students
}

\author{
Zulela MS ${ }^{1}$, Reza Rachmadtullah ${ }^{2}$, Vina Iasha ${ }^{1}$ \\ ${ }^{1}$ Universitas Negeri Jakarta. Jalan Rawamangun Muka, Jakarta Timur 13220. Indonesia \\ ${ }^{2}$ Universitas PGRI Adi Buana, Surabaya. Jalan Dukuh Menanggal XII, Surabaya 60234 Jawa Timur, Indonesia \\ Corresponding Author. E-mail: zulela@unj.ac.id
}

Received: 29 June 2020; Revised: 30 August 2020; Accepted: 15 September 2020

\begin{abstract}
This study aims to determine the effectiveness of the Use of the Effect of Synthetic Analytical Structural Methods on the Beginning Writing Skills of Elementary School Students. This study uses a quantitative method with a type of quasi-experimental research. The results of this study found that there was a significant use of the influence of synthetic analytical structural methods on the ability to write skills in the beginning of grade 2 elementary school students. This is because the Synthetic Analytical Structural Method is a story approach accompanied by an image that contains synthetic analytic elements. Synthetic Analytical Structural method implementation learning techniques are writing card skills, syllable cards, word cards and sentence cards, while some students look for letters, syllables and words, the teacher and some students stick to words arranged into meaningful sentences.
\end{abstract}

Keywords: synthetic analytical structural method, beginning writing skills, elementary school students

How to Cite: MS, Z., Rachmadtullah, R., \& Iasha, V. (2021). Effectiveness of the use of synthetic analytical structural methods against the ability to begin writing skills in elementary school students. Jurnal Prima Edukasia, $\quad$ 9(1), 16-22. doi:https://doi.org/10.21831/jpe.v9i1.33359

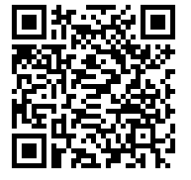

\section{Introduction}

Indonesian is a science that plays an important role in accelerating the mastery of science and technology because Indonesian is a means of thinking to foster a way of thinking logically, systematically, and critically. Considering the importance of Indonesian both in various sciences and in everyday life, Indonesian is taught at every level of education and is an important lesson to master (Alwi et al., 2019; Rahayu, 2007). Learning Indonesian until now has not shown maximum results. Many students have not been able to use Indonesian properly and correctly. Can be seen in several levels of education including tertiary education, even college graduates often make mistakes in using Indonesian language that is good and right (Ardhian et al., 2020; Chuntala, 2019; Suparsa et al., 2017). There is a need for innovation in the optimal learning process in order to improve the learning process of reading and writing beginning in students in the first grade, This is quite reasonable because when students have occupied advanced classes in grade II elementary school, ideally students are ready in terms of reading ability and write further in order to find and find information both explicitly and implicitly in a simple text (Aisyah et al., 2020; Rahmadini et al., 2020; Sari et al., 2020).

In this research, what will be discussed is writing skill, which is certainly not as important as other skills. Writing skills are usually integrated in the learning process. Each subject must have a duty as training and enrichment (MS, Rachmadtullah, et al., 2017; Soewardi \& Maulidyawati, 2018). This is often done in an integrated manner with writing skills. Therefore, writing ability is closely related to various fields of study. To be able to master the skills in writing, it is necessary to learn to start writing.

Beginning writing skills are skills that must be mastered by elementary school students from an early age, because beginning writing skills are very basic skills for elementary school students (Hidayah, 2016; Kurniaman et al., 2018). Beginning writing is a writing skill that is taught in the low class, namely grade 1 and 2 of elementary school as learning to write at the elementary level. The knowledge and abilities gained by students in learning to begin with will be the basis for improving and developing students' abilities at the next level (MS \& Rachmadtullah, 2019; Subandiyah, 2017; Suyitno et al., 2018). If learning to start with what is said to be a basic reference is good and strong, it is expected that the 
Jurnal Prima Edukasia, 9 (1), 2021 - 17

Zulela MS, Reza Rachmadtullah, Vina Iasha

results of developing writing skills to the next level will be good too. Teachers should strive for good learning to guide students to master writing skills from an early age (MS, Siregar, et al., 2017; Sulastri et al., 2020; Susanto, 2019; Tohidian \& Khorsandi Taskoh, 2020).

Writing is an activity to generate thoughts and feelings by writing. It can also be interpreted that writing is communicating in writing expressing thoughts, feelings, and desires to others. Writing skills are one aspect of language skills that must be mastered by every human being, apart from the other three skills, namely reading, listening and speaking.

Writing is a language skill that is used to communicate indirectly. Writing is a productive and expressive activity so that the writer must be able to take advantage of the ability to use writing grammar, language structure, and vocabulary Writing skills are an activity that is inseparable from the teaching and learning activities of students in schools. Writing activities make students active in learning activities and stimulate students' skills in arranging words (Ambarwati \& Budiningsih, 2018; Indriyanti \& Prasetyo, 2018).

However, in practice, many people find it difficult to get students used to learning to write. The cause is an error in teaching that is too rigid gives the impression that writing is difficult. Not many teachers have been able to present subject matter in an appropriate and interesting way. Therefore, it is natural that even students end up being unable and disliking writing lessons (composing). A person is reluctant to write because he does not know what he is writing for, feel gifted writing, and feel do not know how to write. They also experience difficulty in composing sentences, limited vocabulary, and lack of imagination or creativity to think while writing. Dislike cannot be separated from the influence of the environment, family, and society, as well as experiences of learning to write or write in schools that do not motivate and stimulate interest (Sabilillah \& Kurniaman, 2019; Zuraidah et al., 2020).

Research studies that discuss the beginning of writing skills have been done a lot but each target or research location has a different problem, research conducted by Lailiyah and Sukartiningsih (2018) Beginning writing skills can be overcome with interactive learning media but in this study Similar problems about lack of writing skills also occurs in the Elementary School Teacher Education Laboratory of the Jakarta State University. The ability to write beginning grade 2 students is still low. This requires varied learning methods so that students are expected to be enthusiastic in participating in learning to start writing. Pre-observation results most students felt that the initial writing lesson was difficult. Therefore, researchers will try to make changes in learning to begin with. Researchers will use the Synthetic Analytical Structural method.

Synthetic Analytical Structural methods are one of the methods commonly used in the Beginning Writing learning process for beginner students learning to start writing with this method initiating learning by displaying and introducing a complete sentence (Eliastuti \& Irwansyah, 2018). At first the child is treated to a structure that gives full meaning, namely the structure of the sentence. The linguistic basis is that speech is not written, the language element in this method is the sentence. According to (Aida et al., 2018) the understanding of Synthetic Analytical Structural Method is a story approach accompanied by an image, which contains synthetic analytic structural elements. (Rohmatun, 2018) said that the steps of the Synthetic Analytical Structural Method were: (1) The teacher displays the entire sentence, (2) The teacher performs the process of decomposing the sentence, (3) The teacher displays the entire sentence in the original sentence structure. (4) Building concepts of "meaningfulness" in children. It would be better if the sentence structure that is presented as learning material for reading and writing in the beginning with this method is the structure of sentences extracted from the child's language experience.

Based on the description that has been described, this research is considered important because the results of this study are one of the learning treasures that are simple and easy to apply in the beginning of writing learning. Furthermore, the benefits of this research for teachers are to provide input on learning that is interesting and easy for students to understand, so that it can improve initial writing skills. Whereas for students the benefits of this research for teachers is to improve the ability of Grade 2 Elementary School students to start writing.

\section{Method}

This study uses a quantitative method with a type of quasi-experimental research. Quasi experiment research was conducted to determine the effect of a treatment on the characteristics of the 
Jurnal Prima Edukasia, 9 (1), 2021 - 18

Zulela MS, Reza Rachmadtullah, Vina Iasha

subjects studied. In quasi-experimental research it is not possible to control all relevant variables. This study aims to determine the effectiveness of the Use of the Effect of Synthetic Analytical Structural Methods on the Beginning Writing Skills of Elementary School Students.

The research design used in this study was "One Groups Pretest-Posttest Design", which is a research design that contained pretest before being treated and posttest after being treated. Thus it can be known more accurately, because it can be compared with held before being treated (Sugiyono, 2016).

Participants

Participants in this study were grade 2 students of the Private Primary School Lab. Jakarta State University number 30 students. the sample selection of this study uses a sampling technique used in this study is a purposive sampling technique. Statistically, purposive sampling is more appropriate to be used by researchers if indeed a study requires specific criteria so that samples taken later in accordance with research objectives can solve research problems and can provide more representative values. So that the techniques taken can meet the actual purpose of doing research.

Instrument

The instrument used in this study used a modification of the initial writing skills instrument by Ngreni Lestari in 2013 namely the Performance Test used in this study was the assignment and homework of students. The assignment and homework of the student referred to is the writing task in the student's Diary given by the teacher as a habituation and initial writing skills training for students. The task here is the task of writing the beginning given by the teacher after the initial writing material is finished. The aspects of the student writing skills assessment format that have been modified are as follows:

Table 1. Guidelines for Evaluating Student Beginning Writing Skills

\begin{tabular}{lc}
\hline Aspect & Score Range \\
\hline The neatness of writing & $0-10$ \\
Clarity in writing letters & $0-20$ \\
Spelling accuracy & $0-15$ \\
The accuracy of using sentence 0 & $0-15$ \\
Completeness of Words & $0-20$ \\
Conformity with the object & $0-20$ \\
\hline
\end{tabular}

Data analysis technique

Data collection in this study was obtained by holding a pretest and posttest. Pretests are used to measure initial abilities before static fluid learning begins and posttests are used to measure students' abilities after learning is complete. These pretest and posttest are given to the control class and the experimental class. Then the average difference test is carried out with the independent sample t-test with a significance level of 0.05 in the SPSS 24.00 software.

\section{Results and Discussion}

Result

The results of the analysis in this study were to find out how effective the use of Synthetic Analytical Structural Methods Against Beginning Writing Skills of Elementary School Students. As can be explained as follows:

Table 2. Paired Samples Statistics

\begin{tabular}{lcccc}
\hline & Mean & $\mathrm{N}$ & Std. Deviation & Std. Error Mean \\
\hline Pretest & 64.4000 & 30 & 8.42247 & 1.53772 \\
Postets & 82.1333 & 30 & 9.23536 & 1.68614 \\
\hline
\end{tabular}

Based on calculations in the Paired Samples Statistics table above, the average value is seen before using the Use of Synthetic Analytical Structural Methods Against the Writing Skills for Beginning Elementary School Students. amounting to 64.4000 and after being given treatment using the Use of Synthetic Analytical Structural Methods Against the Beginning Skill of Elementary School Students. that is getting an average score of 82.1333 This means that there are descriptive differences in 
Jurnal Prima Edukasia, 9 (1), 2021 - 19

Zulela MS, Reza Rachmadtullah, Vina Iasha

the average before and after the application of the use of Synthetic Analytical Structural Methods Against the Writing Skills of Beginning Elementary School Students.

Table 3. Paired Samples Correlations

\begin{tabular}{ccccc}
\hline & & N & Correlation & Sig. \\
\hline Pair 1 & Pretest \& Postets & 30 & .475 & .008 \\
\hline
\end{tabular}

In the Paired Samples Correlations table above the correlation coefficient obtained for the analysis of the Use of Synthetic Analytical Structural Methods to the Beginning Writing Skills of Elementary School Students. before and after being given the use of Synthetic Analytical Structural Method Against Beginning Writing Skills of Elementary School Students. of 475 with sig, or p-value $=0.008 \geq 0.05$ or not significant.

Table 4. Paired Samples Test

\begin{tabular}{|c|c|c|c|c|c|c|c|}
\hline \multicolumn{5}{|c|}{ Paired Differences } & \multirow{3}{*}{$\mathrm{t}$} & \multirow{3}{*}{ df } & \multirow{3}{*}{$\begin{array}{c}\text { Sig. } \\
\text { (2-tailed) }\end{array}$} \\
\hline \multirow{2}{*}{ Mean } & \multirow{2}{*}{$\begin{array}{c}\text { Std. } \\
\text { Deviation }\end{array}$} & \multirow{2}{*}{$\begin{array}{c}\text { Std. Error } \\
\text { Mean }\end{array}$} & \multicolumn{2}{|c|}{ 95\% Confidence Interval of the Difference } & & & \\
\hline & & & Lower & Upper & & & \\
\hline-17.73333 & 9.07415 & 1.65671 & -21.12168 & -14.34499 & -10.704 & 29 & .000 \\
\hline
\end{tabular}

In the table 4 obtained a mean difference $=-17.73333$ which means the score difference results from the Use of Synthetic Analytical Structural Methods Against the Writing Skills Beginning Skills of Elementary School Students. Positive price means that after being treated the use of Synthetic Analytical Structural Methods Against the Writing Skills Beginning Skills of Elementary School Students. Prices are higher than before being treated. Furthermore, in this table also obtained the mean error standard which shows the standard error rate of the average difference. Furthermore, the most important result of this table is the statistical price of $t=-10,704$ with df 29 and a significant number. Or the p-value 0,000 $<0.05$ or $\mathrm{H} 0$ is rejected. Thus it can be concluded that there are significant differences in results between prior to the use of Synthetic Analytical Structural Methods to the Beginning Writing Skills of Elementary School Students.

Discussion

Beginning writing is the basis of teaching that is first taught by the teacher to first graders. Beginning writing learning skills are presented together with beginning reading. In general, the purpose of this initial writing is to teach children to write so that children can write correctly. But in writing this beginning is usually carried out after or simultaneously with learning to begin reading in first grade children. Because children who can read will facilitate children's learning in beginning writing (Muhyidin et al., 2018; Mulyati, 2011).

The results of research conducted by (Naitili et al., 2019) suggested that the Synthetic Analytical Structural method is one of the types of methods commonly used for the learning process of beginning writing for beginner students. Beginning writing learning with this method begins its learning with two stages, namely displaying and introducing a complete sentence. At first the child is treated to a structure that gives full meaning, namely the structure of the sentence. This is intended to develop the concepts of "meaningfulness" in children. It would be better if the sentence structure that is presented as a learning material for writing in the beginning with this method is the sentence structure that is extracted from the learner's own language experience. For this reason, before the teaching and learning activity of writing the actual beginning begins, the teacher can pre-conduct learning and teaching activities in various ways. For example, the teacher can use pictures, tangible objects, informal question and answer to explore students' languages. Having found a sentence structure that is considered suitable for the initial writing material begins with the introduction of sentence structure (Ayuningtyas et al., 2020; Kurniaman et al., 2020).

Then, through an analytic process, children are invited to get to know the concept of words. The full sentence is used as a basic milestone for learning to begin with and is broken down into smaller language units called words. This analysis or decomposition process continues until it reaches the smallest unit of language that cannot be deciphered, namely letters. Thus, the process of decomposition in learning to write the beginning with the Synthetic Analytical Structural Method, includes: sentences into words; words become syllables; and syllables become letters. 
Jurnal Prima Edukasia, 9 (1), 2021 - 20

Zulela MS, Reza Rachmadtullah, Vina Iasha

There are several principles in learning using Synthetic Analytical Structural Methods. These principles are: (1) sentences are the smallest language elements so teaching using this method must begin by displaying sentences in full and in the form of basic sentence patterns; (2) the structure of the sentences displayed must give rise to clear concepts in the mind / thought of the student. This can be done by displaying it repeatedly so that it stimulates students to know the parts; (3) conduct an analysis of the sentence structure for the displayed sentence structure elements; (4) the found elements are then returned to their original form (synthesis). At this stage, students must be able to find the function of each element and its relationships with one another so that the original elements are re-formed; (5) the structure learned should be the language experience of students so that they are easy to understand and are able to use it in various situations (Dewi, 2018; Eliastuti \& Irwansyah, 2018).

Techniques for implementing Synthetic Analytical Structural Methods are skills in choosing letter cards, word cards, syllable cards, and sentence cards. While some students look for letters, syllables, words, the teacher and some other students paste the words arranged into meaningful sentences. And so on so that all students have a turn to arrange sentences, read them, and cite them as writing skills lessons.

\section{Conclusion}

The reading skills learned by elementary school students are beginning reading. Beginning reading learning aims so that students can recognize and change written symbols into meaningful sounds, or in other words to make students literate. This means that students who used to not know letters become taboo letters, so that they can pronounce the letters according to the sound. Given the importance of learning to read, teachers are required to be able to present learning materials to begin with reading well. Presenting well, means preparing, implementing, and evaluating with full accuracy. Synthetic Analytical Structural Methods can stimulate students to involve themselves actively, because students in addition to listening, reciting, and taking notes, also use props. Thus, it is possible that the Synthetic Analytical Structural method will be effective if it is used in the learning of beginning reading in elementary school students

\section{Reference}

Aida, S., Nasirun, M., \& Suprafti, A. (2018). Meningkatkan keterampilan membaca awal melalui metode struktural analitik sintetik. Jurnal Ilmiah Potensia, 3(2), 111-118. https://doi.org/10.33369/jip.3.2.111-118

Aisyah, S., Yarmi, G., Sumantri, M. S., \& Iasha, V. (2020). Kemampuan membaca permulaan melalui pendekatan whole language di sekolah dasar. Jurnal Basicedu, 4(3), 637-643. https://doi.org/10.31004/basicedu.v4i3.393

Alwi, H., Dardjowidjojo, S., Lapoliwa, H., \& Moeliono, A. M. (2019). Tata bahasa baku bahasa Indonesia. Balai Pustaka.

Ambarwati, W., \& Budiningsih, C. A. (2018). The effectiveness of video and deck card use in crafting the skills of writing experience within the elementary school students. Jurnal Prima Edukasia, 6(2), 177-188. https://doi.org/10.21831/jpe.v6i2.9781

Ardhian, T., Ummah, I., Anafiah, S., \& Rachmadtullah, R. (2020). Reading and critical thinking techniques on understanding reading skills for early grade students in elementary school. International Journal of Instruction, 13(2), 107-118. https://doi.org/10.29333/iji.2020.1328a

Ayuningtyas, L., Indrianti, D. T., \& Hilmi, M. I. (2020). Implementasi metode struktural analitik sintetik pada program keaksaraan fungsional di Kabupaten Jember. Learning Community: Jurnal Pendidikan Luar Sekolah, 3(2), 66. https://doi.org/10.19184/jlc.v3i2.16804

Chuntala, A. D. W. (2019). Saintific approach in 21st century learning in indonesian language learning vocational school of pharmacy. International Journal of Active Learning, 4(2), 71-77. https://doi.org/10.15294/ijal.v4i2.17181

Dewi, C. (2018). Penggunaan metode SAS (struktural analitik sintetik) dalam pembelajaran bahasa Indonesia menulis permulaan siswa sekolah dasar. BAHASTRA, 38(1), 8. https://doi.org/10.26555/bahastra.v38i1.8174

Eliastuti, M., \& Irwansyah, N. (2018). Keefektifan membaca menggunakan metode struktural analitik 
Jurnal Prima Edukasia, 9 (1), 2021 - 21

Zulela MS, Reza Rachmadtullah, Vina Iasha

sintetik (SAS) pada siswa yang kesulitan membaca. DEIKSIS, 10(01), 33.

https://doi.org/10.30998/deiksis.v10i01.2265

Hidayah, W. (2016). Peningkatan keterampilan menulis permulaan menggunakan buku harian siswa kelas I A SD N Plebengan Sidomulyo Bantul tahun 2015/2016. Basic Education, 5(28). http://journal.student.uny.ac.id/ojs/index.php/pgsd/article/view/4853

Indriyanti, R., \& Prasetyo, Z. K. (2018). Improving the experiment report writing skills of fifth graders through the discovery learning method. Jurnal Prima Edukasia, 6(1), 102-110. https://doi.org/10.21831/jpe.v6i1.17284

Kurniaman, O., Maharani, D. S., Noviana, E., \& Afendi, N. (2020). Development of linguistic intelligence instruments for elementary schools student. ELS Journal on Interdisciplinary Studies in Humanities, 3(1), 85-96.

Kurniaman, O., Yuliani, T., \& Mansur, M. (2018). Investigating think talk write (TTW) learning model to enhance primary students' writing skill. Journal of Teaching and Learning in Elementary Education (JTLEE), 1(1), 52. https://doi.org/10.33578/jtlee.v1i1.5394

Lailiyah, N., \& Sukartiningsih, W. (2018). Pengembangan media pembelajaran interaktif berbasis flash untuk pembelajaran keterampilan menuliskan kembali cerita siswa kelas IV SD. Jurnal Penelitian Pendidikan Guru Sekolah Dasar, 6(7).

https://jurnalmahasiswa.unesa.ac.id/index.php/jurnal-penelitian-pgsd/article/view/23963

MS, Z., \& Rachmadtullah, R. (2019). Constructivism approach in learning to write narrative at elementary school. Proceedings of the 1st International Conference on Innovation in Education (ICoIE 2018). https://doi.org/10.2991/icoie-18.2019.64

MS, Z., Rachmadtullah, R., \& Siregar, Y. E. Y. (2017). Strategi guru meningkatkan pemahaman bacaan melalui pendekatan savi pada siswa kelas V sekolah dasar. Jurnal Pendidikan Dasar, 8(1). http://journal.unj.ac.id/unj/index.php/jpd/article/view/5350

MS, Z., Siregar, Y. E. Y., Rachmadtullah, R., \& Warhdani, P. A. (2017). Keterampilan menulis narasi melalui pendekatan konstruktivisme di sekolah dasar. Jurnal Pendidikan Dasar, 8(2), 112-123. http://journal.unj.ac.id/unj/index.php/jpd/article/view/5359

Muhyidin, A., Rosidin, O., \& Salpariansi, E. (2018). Metode pembelajaran membaca dan menulis permulaan di kelas awal. Jurnal Pendidikan Sekolah Dasar, 4(1), 30. https://doi.org/10.30870/jpsd.v4i1.2464

Mulyati, Y. (2011). Pembelajaran membaca dan menulis permulaan. In Modul.

Naitili, C. A., Suardana, I. M., \& Ramli, M. (2019). Penerapan metode struktural analitik sintetik untuk meningkatkan keterampilan menulis permulaan siswa sekolah dasar. Jurnal Pendidikan: Teori, Penelitian, Dan Pengembangan, 4(5), 660-667. https://doi.org/10.17977/jptpp.v4i5.12463

Rahayu, M. (2007). Bahasa Indonesia di perguruan tinggi. Grasindo.

Rahmadini, R., S, Z. M., Sumantri, M. S., \& Iasha, V. (2020). Pembimbingan peserta didik kelas awal yang mengalami hambatan dalam membaca permulaan. Elementary School: Jurnal Pendidikan Dan Pembelajaran Ke-SD-An, 7(2). https://doi.org/10.31316/esjurnal.v7i2.708

Rohmatun, W. P. (2018). Pembelajaran keterampilan membaca nyaring tematik bahasa Indonesia Kurikulum 2013 dengan metode struktur analisis sintesis (SAS) siswa sekolah dasar. Stilistika: Kajian Bahasa, Sastra, Dan Pembelajarannya, 4(2). https://doi.org/10.32585/.v4i2.333

Sabilillah, N. S., \& Kurniaman, O. (2019). Developing a big book has a conservation character in early reading. Jurnal Prima Edukasia, 7(2), 162-171. https://doi.org/10.21831/jpe.v7i2.22855

Sari, Y., Luvita, R. D., Cahyaningtyas, A. P., Iasha, V., \& Setiawan, B. (2020). Pengaruh metode pembelajaran struktural analitik sitentik terhadap kemampuan menulis permulaan di sekolah dasar. Jurnal Basicedu, 4(4), 1125-1133. https://doi.org/10.31004/basicedu.v4i4.515

Soewardi, H., \& Maulidyawati, S. B. (2018). Educative doll design as media for learning indonesian traditional folk song using affective design approach. International Journal of Information and Education Technology, 8(12), 874-879. https://doi.org/10.18178/ijiet.2018.8.12.1156

Subandiyah, H. (2017). Pembelajaran literasi dalam mata pelajaran bahasa indonesia. Paramasastra, Copyright (C) 2021, Jurnal Prima Edukasia, ISSN 2338-4743 (print), ISSN 2460-9927 (online) 
Jurnal Prima Edukasia, 9 (1), 2021 - 22

Zulela MS, Reza Rachmadtullah, Vina Iasha

2(1). https://doi.org/10.26740/parama.v2n1.p\%25p

Sugiyono. (2016). Metodologi penelitian kuantitatif, kualitatif, dan R\&D. CV Alfabeta.

Sulastri, S., Hartati, N. T., \& Herawati, I. A. (2020). Implementation of techno pedagogy approchbased multiliteration models in improving the skills of writing the narration of elementary school students. International Conference on Elementary Education, 2(1), 1318-1326. http://proceedings2.upi.edu/index.php/icee/article/view/752

Suparsa, I. N., Mantra, I. B. N., \& Widiastuti, I. A. M. S. (2017). Developing learning methods of Indonesian as a foreign language. International Journal of Social Sciences and Humanities, 1(2), 51-57. https://doi.org/10.29332/ijssh.v1n2.41

Susanto, S. (2019). Peningkatan keterampilan menulis puisi siswa kelas III SDN Bringin 1 Kecamatan Bringin Kabupaten Ngawi dengan menggunakan teknik akrostik. Jurnal Pendidikan Modern, 4(3), 28-36. https://doi.org/10.37471/jpm.v4i3.11

Suyitno, I., Susanto, G., Kamal, M., \& Fawzi, A. (2018). Cognitive learning strategy of BIPA students in learning the Indonesian language. IAFOR Journal of Language Learning, 3(2). https://doi.org/10.22492/ij1l.3.2.08

Tohidian, I., \& Khorsandi Taskoh, A. (2020). Teacher's narration of teaching critical literacy: It's a KEY for raising students' awareness in Iran. Multidisciplinary Journal of Educational Research, 10(1), 75. https://doi.org/10.17583/remie.2020.4714

Zuraidah, S., Syamsi, K., \& Ashadi, A. (2020). Improving the story-telling skill of grade 1 students through the use of hand puppet media. Jurnal Prima Edukasia, 8(2), 166-176.

https://doi.org/10.21831/jpe.v8i2.33831 